\title{
$\alpha$-GALACTOSIDASE ACTIVITY AND CARBOHYDRATE MOBILIZATION IN SEEDS OF Dalbergia nigra (Vell.) Allemão ex Benth. - FABACEAE (BRAZILIAN ROSEWOOD) DURING GERMINATION
}

\author{
Lanna Clicia Carrijo ${ }^{1}$, Eduardo Euclydes de Lima e Borges ${ }^{2}$, \\ Claudia Aparecida Pontes ${ }^{3}$, Mariana Rocha Lopes ${ }^{4}$, Arno Brune ${ }^{5}$
}

(received: January 5, 2009; accepted: April 30, 2010)

\begin{abstract}
Complex substances are converted by enzyme action into soluble molecules during the germination process, and these are in turn translocated to the growing plant embryo, serving as an energy source or physical structure. With the objective of quantifying $\alpha$-galactosidase enzyme activity as well as mono- and oligosaccharide mobilization during germination, this study was conducted using Brazilian rosewood seeds. Seeds were kept in a germinator at $25^{\circ} \mathrm{C}$ under continuous light for evaluation of radicle emergence (protrusion) over a period of 10 days. Mono- and oligosaccharide contents and also the specific activity of $\alpha$-galactosidase enzyme were quantified on days zero, one, three and five. There was mobilization of glucose and mannose stored in cotyledons, and also of xylose in cotyledons and in the embryo in the first three days of germination. Rhamnose contents increased in cotyledons and in the embryonic axis. Raffinose was the initially used oligosaccharide, both in the embryonic axis and in cotyledons, while sucrose accumulated in both. Enzyme activity varied throughout, with greater specific activity on day one of imbibition, both in cotyledons and in the embryonic axis.
\end{abstract}

Key words: Physiology, enzyme, reserves.

\section{ATIVIDADE DE $\alpha$-GALACTOSIDASE E MOBILIZAÇÃO DE CARBOIDRATOS EM SEMENTES DE Dalbergia nigra (Vell.) Alemão ex Benth. - FABACEAE (JACARANDÁ-DA-BAHIA) DURANTE A GERMINAÇÃo}

RESUMO: Substâncias complexas são convertidas, pela ação de enzimas, em moléculas solúveis, durante o processo de germinação, as quais são translocadas para a plântula em crescimento, servindo como fonte de energia ou estrutura física. Com o objetivo de quantificar a atividade enzimática da a-galactosidase e a mobilização de mono e oligossacarídeos durante o período de germinação, foi conduzido este estudo utilizando-se sementes de jacarandá-da-bahia. As sementes foram mantidas em germinador $a 25^{\circ} \mathrm{C}$ sob luz contínua, sendo avaliada a protrusão da radícula, pelo período de 10 dias. Foram quantificados os teores de mono e de oligossacarídeos, assim como a atividade específica da enzima $\alpha$-galactosidase nos tempos zero, um, três e cinco dias. Houve mobilização das reservas de glicose e manose nos cotilédones exilose neste e no embrião nos três primeiros dias de germinação. A ramnose teve os teores aumentados nos cotilédones e no eixo embrionário. A rafinose foi o oligossacarídeo utilizado inicialmente, tanto no eixo embrionário, quanto nos cotilédones, enquanto a sacarose acumulou-se em ambos. A atividade da enzima variou no período estudado, com maior atividade específica no primeiro dia de embebição, tanto nos cotilédones, quanto no eixo embrionário.

Palavras-chave: Fisiologia, enzima, reservas.

\section{INTRODUCTION}

Knowledge of constituent elements of reserves is of great importance to seed technology, since vigor and germination, and consequently storage potential, are all influenced by compounds present (CARVALHO \& NAKAGAWA 2000). The seed germination process mobilizes different stored substances (BASKIN \& BASKIN 1998, BORGES \& RENA 1993). Changes observed during germination can vary between species and between different process phases (STONE \& GIFFORD 1999). Pontes et al. (2002) observed in Apuleia leiocarpa seeds that carbohydrates, lipids and proteins were mobilized in cotyledons and in the embryonic axis after germination.

\footnotetext{
${ }^{1}$ Biochemist, M.Sc. candidate in Agricultural Biochemistry - Universidade Federal de Viçosa - BIOAGRO - Av. Peter Henry Rolfs, s/n, Campus Universitário - 36571-000 - Viçosa, MG, Brasil - lannaclicia@gmail.com

${ }^{2}$ Forest Engineer, Dr. Professor of Ecology and Natural Resources - Departamento de Engenharia Florestal - Universidade Federal de Viçosa - Av. Peter Henry Rolfs, s/n, Campus Universitário - 36571-000 - Viçosa, MG, Brasil - elborges@ufv.br

${ }^{3}$ Forest Engineer, Dr. Professor of Forest Sciences - Instituto Federal Minas Gerais - Campus São João Evangelista - Avenida Primeiro de Junho, 1043, Centro - 39705-000 - São Joao Evangelista, MG, Brasil - pontesac@ gmail.com

${ }^{4}$ Biochemist, M.Sc. candidate in Agricultural Biochemistry - Departamento de Biologia Molecular - Universidade Federal de Viçosa - Av. Peter Henry Rolfs, s/n, Campus Universitário - 36571-000 - Viçosa, MG, Brasil - mariana_bqi@yahoo.com.br

${ }^{5}$ Dr. Professor of Forest Improvement - Faculdade de Engenharia Florestal - Universidade Federal do Mato Grosso - Av. Fernado Correa da Costa, s/n, Campus Universitário - 78060-900 - Cuibá, MT, Brasil - arnobrune @ hotmail.com
}

Cerne, Lavras, v. 16, n. 3, p. 283-289, jul./set. 2010 
According to Tiné et al. (2000), xyloglucan is degraded in Hymenaea courbaril seeds 35 to 55 days after seed planting. Raffinose-series oligosaccharides were used in the imbibition process while galactomannan reserves were used in the growth process of the plant embryo in Sesbania marginata seeds (BUCKERIDGE \& DIETRICH 1996).

According to Dey (1981), the $\alpha$-galactosidase enzyme is widely distributed among leguminous plants and is active in dormant seeds (GUIMARÃES et al. 2001). According to Feurtado et al. (2001), $\alpha$-galactosidase was detected in the embryo and also in lateral and micropylar portions of the endosperm in Lycopersicon esculentum seeds. Borges et al. (2002), on the other hand, found no relationship between $\alpha$-galactosidase activity and changes in the composition of the cell wall or in sugar contents in Platimiscium pubescens seeds during germination. After its characterization in cotyledons and in the embryonic axis of dormant Caesalpinia peltophoroides seeds, Borges et al. (2005) concluded that it is present in different isoforms within seed structures.

Brazilian rosewood is a tree native to Atlantic Forest domain in Bahia, Espírito Santo, Rio de Janeiro, São Paulo and Minas Gerais states (LORENZI 1992). Its wood is moderately heavy, decorative, naturally longlasting and widely used in the manufacture of luxury furniture, in building construction and general landscaping (OLIVEIRA FILHO 1994, PIÑARODRIGUES \& PIRATELLI 1993). Due to being indiscriminately explored, it is now threatened with extinction and listed as a vulnerable species in the 'official inventory' of flora under threat of extinction (BRAZILIAN ENVIRONMENTAL INSTITUTE - IBAMA 2008). Despite being endangered, information is nonetheless scarce on the physiology of seed germination in this species.

This study was conducted with the objective of characterizing carbohydrate and $\alpha$-galactosidase mobilization in cotyledons and in the embryonic axis of Brazilian rosewood during seed germination.

\section{MATERIAL AND METHODS}

Fruits of Brazilian rosewood were picked from two trees in Viçosa, MG state, on 12 September 2007. Unripe, rotten and damaged fruits were discarded and remaining fruits were stored in burlap bags and placed in a coldstorage room at $5^{\circ} \mathrm{C}$ for six months.

Cerne, Lavras, v. 16, n. 3, p. 283-289, jul./set. 2010
The germination test was carried out according to Borges et al. (2000), using petri dishes with doublelined germitest paper moistened with distilled water, which were kept in a germinator at $25^{\circ} \mathrm{C}$ under continuous light as provided by four $40 \mathrm{~W}$ special daylight white fluorescent lamps, for 10 days. Five replicates were used, each with 20 seeds, in which all seeds presenting radicle emergence were considered as being germinated. Assessments were made of both germination and substrate moisture level every 24 hours.

Cotyledon and embryonic axis samples were collected at the start and 24, 72 and 120 hours after imbibition, then oven-dried at $45^{\circ} \mathrm{C}$ to constant weight, and stored tightly in glass jars at $-5^{\circ} \mathrm{C}$, until extraction and quantification of stored substances. Seeds presenting radicle emergence at 72 and 120 hours were eliminated.

Extractions of reducing sugars and oligosaccharides were done according to a modified methodology proposed by Black et al. (1996), with alterations. Dry, ground samples of cotyledons and embryonic axis were homogenized separately using ethanol $80 \%$ at $75^{\circ} \mathrm{C}$ for 30 minutes, and then centrifuged for 10 minutes at $17000 \mathrm{G}$. Supernatants were mixed and used for the analysis. The extraction process was repeated four times for complete removal of sugars and oligosaccharides.

Monosaccharides were transformed into alditol acetate for quantification by gas chromatography (ENGLYST \& CUMMINGS 1984). Chromatograms were obtained using a Shimadzu $25 \mathrm{~m}$ column, injecting $1 \mu \mathrm{L}$ of sample. Column, injector and detector temperatures were set at $220^{\circ} \mathrm{C}, 250^{\circ} \mathrm{C}$ and $275^{\circ} \mathrm{C}$ respectively. Three replicates were used, each one in duplicate.

The oligosaccharide samples were filtered, evaporated and ressuspended with $500 \mu \mathrm{L}$ of ultrapure water. Oligosaccharides were quantified after passing samples in a C-18 Sep-pak column to separate protein and, after the volume was reduced, $20 \mu \mathrm{L}$ of sample was injected into a Shimadzu high-performance liquid chromatographer (HPLC) equipped with a $300 \mathrm{~mm} \times 7.8 \mathrm{~mm} \mathrm{HPX}-42 \mathrm{C}$ amine column, using distilled water as mobile phase and a $0.5 \mathrm{~mL}$ $\min ^{-1}$ flow. The apparatus was equipped with a refractive index detector.

Extract preparation and enzyme activity quantification were performed according to a modified methodology proposed by Viana (2002). A 100mg sample of each seed part (cotyledons and embryonic axis) was 
macerated in $1.5 \mathrm{~mL}$ of sodium acetate buffer (100mM, pH 5), using a porcelain mortar in ice bath. Following maceration, the sample was centrifuged at $17000 \mathrm{G}$ for 20 minutes at $4^{\circ} \mathrm{C}$. The supernatant was used to quantify $\alpha$-galactosidase enzyme activity.

The $\alpha$-galactosidase activity was assessed by adding $\rho$-nitrophenyl galactopyranoside ( $\rho$-NPGal) $2.0 \mathrm{mM}$ to the enzyme extract, followed by bain-marie incubation at $37^{\circ} \mathrm{C}$ for 15 minutes. $1.0 \mathrm{~mL}$ of $0.5 \mathrm{M}$ sodium carbonate was added to stop the reaction. A reading was taken at $410 \mathrm{~nm}$, and absorbance values were transformed into micromoles of $\rho-\mathrm{NP}$ (paranitrophenyl), using a standard curve of $\rho$-NP. One activity unit (U) was defined as being the amount of enzyme necessary to derive $1.0 \mu \mathrm{M}$ of $\rho$-NP, per minute, under experimental conditions. Three replicates were performed, and the average value of triplicate determination was computed.

The experiment was set up in a completely randomized design, with three replicates of $600 \mathrm{mg}$ samples oven-dried at $45^{\circ} \mathrm{C}$ for 24 hours, for analysis of sugars. Enzyme analysis was done with three replicates, the average value of triplicates being computed.

\section{RESULTS AND DISCUSSION}

Seeds began to show radicle emergence on day three of imbibition and reached $90 \%$ of germination within 10 days (Figure 1 ).

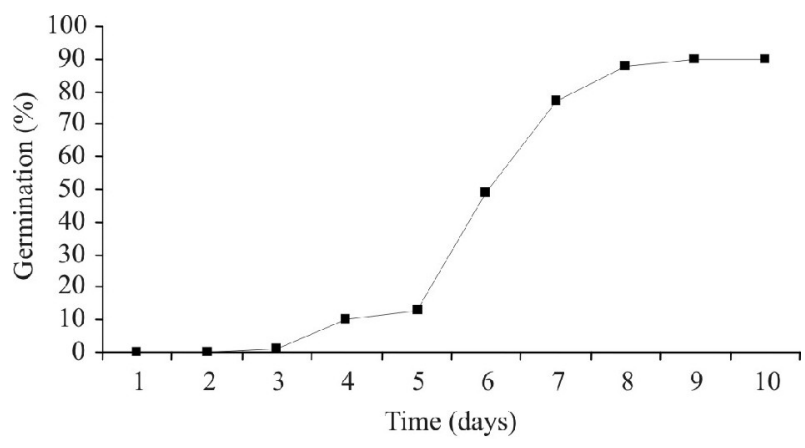

Figure 1 - Cumulative germination percentage in Brazilian rosewood seeds (Dalbergia nigra).

Figura 1 - Porcentagem cumulativa de germinação de sementes de jacarandá-da-bahia (Dalbergia nigra).

Rego \& Possamai (2003) observed 75\% germination in seeds of the same species. These result variations can be explained by both site of collection and seed storage time. No information is available for this particular species about these aspects, yet research data on Copaifera langsdorffii seeds showed variations in germination and in germination rate in two different sites of collection (RODRIGUES et al. 2007). Similarly, significant differences were detected depending on origin and origin X temperature interaction in Ceiba pentandra seeds (SOUSA et al. 2000). In the latter case, stored seeds, traditional and recalcitrant, are known to lose quality depending on the temperature and/or moisture conditions, with faster or slower deterioration accordingly. Also, Anadenanthera peregrina seeds were noted to have reduced feasibility when stored at $20^{\circ} \mathrm{C}$ for five months (PINHO et al. 2009).

Average monosaccharide contents in cotyledons and in the embryonic axis are illustrated in Figure 2.
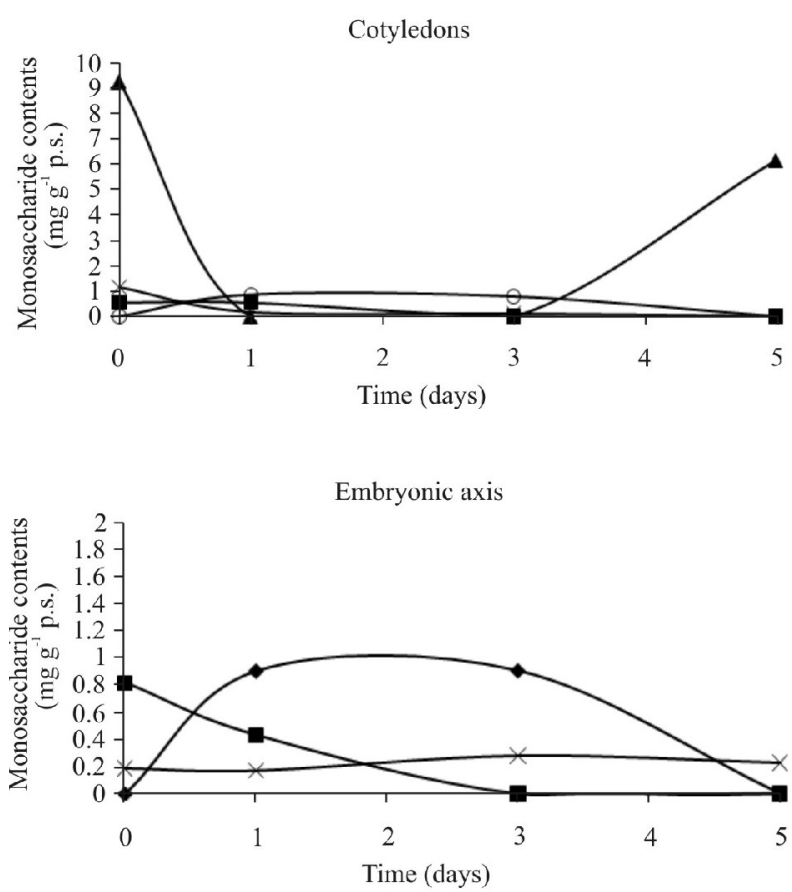

Figure 2 - Average monosaccharide contents in cotyledons and in the embryonic axis of Brazilian rosewood seeds (Dalbergia nigra), during the germination period. Rhamnose ; xylose $\square$; mannose $\mathbf{\Delta}$; glucose $\square$.

Figura 2 - Teores médios de monossacarídeos nos cotilédones e no eixo embrionário de sementes de jacarandá-da-bahia (Dalbergia nigra), durante o período de germinação. Ramnose ; xilose $\square$; manose $\boldsymbol{\Delta}$; glicose $\square$.

Cerne, Lavras, v. 16, n. 3, p. 283-289, jul./set. 2010 
Initially read as zero, rhamnose contents in cotyledons and in the embryonic axis increased from day one of imbibition, returning to zero on day five. This increase could be a result of cell wall degradation in both structures and nonuse to start with but later use when a significant increase occurred in the germination percentage (Figure 1), indicating its possible use in the formation of embryonic physical structures. Borges et al. (2005) observed no significant variations in average contents of this monosaccharide in Caesalpinia peltophoroides seeds, during imbibition.

Galactose was not detected in the embryonic axis or in cotyledons during imbibition, indicating a possibly more intense use in the formation of the physical structure during embryonic axis growth. Another possibility is its elimination into the medium, avoiding its negative influence on the germination process. Borges et al. (2004) observed that galactosidase inhibited $\alpha$ galactosidase activity in the embryonic axis and cotyledon in Caesalpinia peltophoroides seeds, yet Borges et al. (2005) obtained a different result with Platymiscium pubescens seeds.

Initially present in cotyledons and in the embryonic axis, xylose was not detected from day three of imbibition, when seeds presenting radicle emergence were first noticed, indicating its possible use in physical structures.

Mannose was present in larger quantities in cotyledons at time zero of imbibition, in comparison to other monosaccharides, disappearing during the first three days and being again detected on day five. It may have been used as an energy source during that period, through respiration, and/or as a constituent element of the physical structure during embryonic growth, with mobilization of cotyledon reserves from day one. It was not detected in the embryonic axis, which reinforces the possibility of its use. Another possibility is that it may have been eliminated into the medium during imbibition, similarly to what was observed by Borges et al. (2002) in Platymiscium pubescens seeds, when a significant reduction was noticed in rhamnose, xylose and galactose contents. Average mannose contents increased significantly in cotyledons during imbibition in Apuleia leiocarpa seeds, denoting variations in behavior depending on the species (PONTES et al. 2002).

The glucose content remained stable in the embryonic axis but was not detected in cotyledons (Figure 2). As this monosaccharide is a substrate for respiration and physical structures, it is assumed that little was used during imbibition, allowing it to remain stable in the embryo. Alternatively, there may have been an interconversion of monosaccharides and as a result of this restoring mechanism its use remains unaltered, as was observed in potato tubercles (OOMEN et al. 2004) and in Arabdopsis thaliana plants (RÖSTI et al. 2007). In Apuleia leiocarpa seeds, according to Pontes et al. (2002), glucose contents in cotyledons remained reasonably unaltered during imbibition.

Average contents of oligosaccharides sucrose, raffinose and stachyose in cotyledons and in the embryonic axis are illustrated in Figure 3.
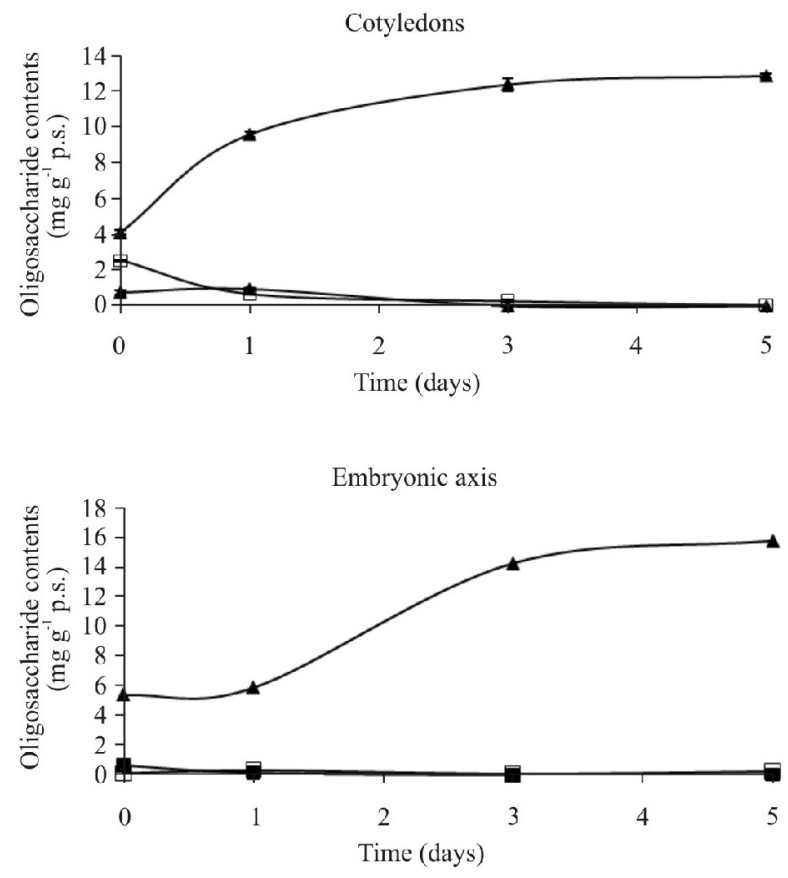

Figure 3 - Average sucrose, raffinose and stachyose contents in cotyledons and in the embryonic axis of Brazilian rosewood seeds (Dalbergia nigra), during the germination period. Stachyose: $\square$; raffinose: $\square$; sucrose: $\triangle$

Figura 3 - Teores médios de sacarose, rafinose e estaquiose nos cotilédones e no eixo embrionário de sementes de jacarandáda-bahia (Dalbergia nigra), durante o período de germinação. Estaquiose: $\square$; rafinose: $\square$; sacarose:

Sucrose is the main constituent oligosaccharide found in cotyledons and in the embryonic axis during the analyzed period (Figure 3 ), with average contents increasing throughout the study period, in both structures.

Average raffinose contents decreased throughout the imbibition period, in both structures (Figure 3 ). This oligosaccharide was not detected in the embryonic axis 
from day two of imbibition. Raffinose-family oligosaccharides are used as an energy source during germination, as cited by Guimarães et al. (2001), which might explain results.

The average stachyose content in cotyledons (Figure 3) decreased from day one of imbibition and was not detected anymore in the last two days. In the embryonic axis, this oligosaccharide showed slight variation throughout (Figure 3).

Comparing glucose and galactose data to sucrose data, it can be assumed that the low contents of the first two may result from incorporation into the oligosaccharide in both compartments. This assumption is reinforced by the nondetection of fructose, a component of both oligosaccharides.

Figure 4 illustrates the relationship between specific activity of $\alpha$-galactosidase and imbibition time in cotyledons and in the embryonic axis of Brazilian rosewood seeds.

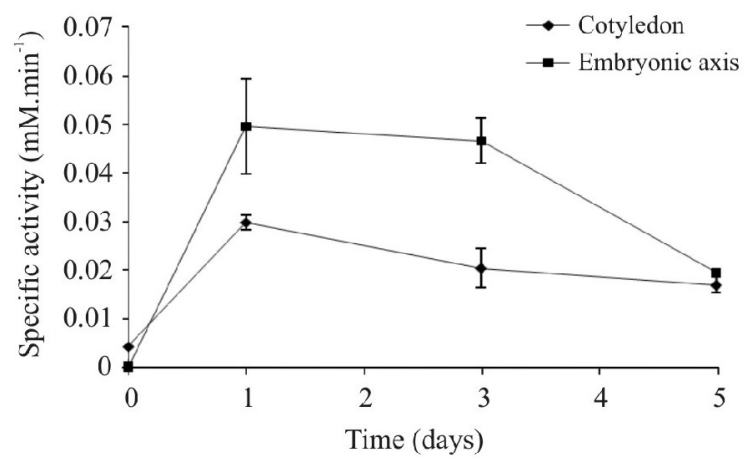

Figure 4 - Specific activity of $\alpha$-galactosidase in cotyledons and in the embryonic axis of Brazilian rosewood seeds (Dalbergia nigra), during the germination period.

Figura 4 - Atividade específica da $\alpha$-galactosidase nos cotilédones e eixo embrionário de sementes de jacarandá-dabahia (Dalbergia nigra), durante o período de germinação.

The above enzyme showed no activity in the embryonic axis and proved low in cotyledons at time zero of imbibition, increasing in both structures after 24 hours of imbibition, with $0.05 \mathrm{mM} \mathrm{min}^{-1}$ and $0.03 \mathrm{mM} \mathrm{min}^{-1}$ being detected in the embryonic axis and cotyledon respectively. Its activity remained high and constant in the embryonic axis between day one and day three of imbibition, followed by a decrease to the same level found in cotyledons on day five. In cotyledons, its activity decreased after day one of imbibition (Figure 4).
According to Borges et al. (2005), $\alpha$-galactosidase is active in Caesalpinia peltophoroides seeds even before imbibition and increases activity with imbibition, being higher in the embryonic axis than in cotyledons. Oliveira et al. (2006) observed that the specific activity of $\alpha$-galactosidase in seeds of Platymiscium pubescens and Senna macranthera, differently to results in this work, decreased after $96 \mathrm{~h}$ of imbibition. Comparing Figure 4 data to results obtained for monosaccharides, no relationship is noted between enzyme activity and absence of galactose, a component of galactomannan, a substrate of $\alpha$-galactosidase. The enzyme could be acting in one or two layers of galactomannan present in the seed tegument. That way, the product of digestion could be being eliminated in the imbibition water or else being metabolized in cells or being physically incorporated into their structure. According to Lahuta et al. (2000), ripe seeds have different forms of $\alpha$-galactosidase (isoenzyme) as far as activity and molecular mass are concerned. Thus different enzyme forms could be related to the seed's physiological stage.

\section{CONCLUSIONS}

Seeds of Dalbergia nigra (Brazilian rosewood) presented variations in the specific activity of $\alpha$ galactosidase enzyme and also in monosaccharide contents, in both structures.

Sucrose contents increased continually throughout in both structures of Brazilian rosewood seeds, with raffinose being the first used.

\section{BIBLIOGRAPHICAL REFERENCES}

BASKIN, C. C.; BASKIN, J. M. Seeds: ecology, biogeography and evolution of dormancy and germination. San Diego: Academic, 1998. $666 \mathrm{p}$.

BLACK, M.; CORBINEAU, F.; GRZESIK, M.; GUY, P.; CÔME, D. Carbohydrate metabolism in the developing and maturing wheat embryo in relation to is desiccation tolerance. Journal Experiment of Botanic, Oxford, v. 47, n. 295, p. 161-169, 1996.

BORGES, E. E. L.; BORGES, R. C. G.; BUCCKRIDGE, M. S Alterações nas composições de carboidratos e ácidos graxos em sementes de jacarandá-da-bahia osmocondicionadas. Revista Brasileira de Fisiologia Vegetal, v. 12, n. 1, p. 10-16, 2000.

BORGES, E. E. L.; BORGES, R. C. G.; SOARES, C. P. B.; PEREZ, S. C. J. G. A. Crescimento e mobilização de carboidrato em embrião de sementes de fedegoso (Senna macranthera Irwin et Barneby) durante a germinação. Cerne, Lavras, v. 8, n. 1, p. 69-76, 2002.

Cerne, Lavras, v. 16, n. 3, p. 283-289, jul./set. 2010 
BORGES, E. E. L.; PEREZ, S. J. G. A.; BORGES, R. C. G.; REZENDE, S. T.; GARCIA, S. R. Comportamento fisiológico de sementes osmocondicionadas de Platymiscium pubescens Micheli (tamboril-da-mata). Revista Árvore, Viçosa, v. 26, n. 5, p. 603-613, 2002.

BORGES, E. E. L.; RENA, A. B. Germinação de sementes. In: AGUIAR, I. B.; PIÑA-RODRIGUES, F. C. M.; FIGLIOTA, M. B. Sementes florestais tropicais. Brasília: Associação Brasileira de Tecnologia de sementes, 1993. $350 \mathrm{p}$.

BORGES, E. E. L.; REZENDE, S. T.; BORGES, R. C. G.; PEREZ, S. C. J. G. A. Caracterização de alfa-galactosidase e sua relação com a germinação das sementes de Platymiscium pubecens Michel, var. pubecens (tamboril da mata). Revista Brasileira de Sementes, Porto Alegre, v. 26, n. 2, p. 82-90, 2004.

BORGES, E. E. L.; REZENDE, S. T.; BORGES, R. C. G.; PEREZ, S. C. J. G. A. Caracterização de alfa-galactosidase e sua relação com a germinação das sementes de Caesalpinia peltophoroides (Leguminosae Caesalpinoideae). Revista Árvore, Viçosa, v. 29, n. 4, p. 525-533, 2005.

BUCKERIDGE, M. S.; DIETRICH, S. M. C. Mobilization of the raffinose family oligosaccharides and galactomannan in germinating seeds of Sesbania marginata Benth. (LeguminosaeFaboideae). Plant Science, Amsterdam, v. 117, p. 33-43, 1996.

CARVAlHO, N. M.; NAKAGAWA, J. Sementes: ciência, tecnologia e produção. 4. ed. Jaboticabal: Funep, 2000. 258 p.

DEY, P. M. $\alpha$-galactosidase from sweet chestnut seeds. Phyctochemistry, Amsterdam, v. 20, p. 1493-1496, 1981.

ENGLYST, H. N.; CUMMINGS, J. H. Simplified method for the measurement of total non-start polysaccharides by gas-liquid chromatograph of constituent sugars as alditol acetates. Analyst, Cambridge, v. 109, p. 973-942, 1984.

FEURTADO, J. A.; BANIK, M.; BEWLEY, J. D. The clonning and characterization of alphagalactosidase present during and following germination of tomato (Lycopersicon esculentum Mill) seed. Journal Experimental of Botany, Lancaster, v. 52, n. 359, p. 1239-1249, 2001.

GUIMARÃES, V. M. et al. Characterization of $\alpha$-galactosidase from germinating soybean seed and their use for hydrolysis of oligosaccharides. Phytochemistry, Amsterdam, v. 58, p. 67-73, 2001.
INSTITUTO BRASILEIRO DE MEIO AMBIENTE. Lista official de Flora ameaçada de extinção. Disponível em: <http:// www.mma.gov.br/estruturas/ascom_boletins/ arguivosh $183=19092008034949$.pdf $>$. Acesso em: 30 jun. 2009.

LAHUTA, L.; GORECKI, R. J.; MICHALCZYK, D.; PIOTROWICZCIESLAK, A. L. C. Alpha-D-galactosidase activity in stored yellow lupin (Lupinus luteus L.) seeds. Electronic Journal Polish Agriculture, v. 3, p. 1-10, 2000.

LORENZI, H. Árvores brasileiras: manual de identificação e cultivo de plantas arbóreas nativas do Brasil. Nova Odessa: Platarum, 1992. 352 p.

OLIVEIRA, G.; GUIMARÃES, V. M.; BORGES, E. E. L.; FIALHO, L. S.; OLIVEIRA, M. G. A.; REZENDE, S. T. Purificação e caracterização de $\alpha$-galactosidases de sementes de Platymiscium pubescens Micheli. Revista Árvore, Viçosa, v. 30, n. 3, p. 359-367, 2006.

OLIVEIRA FILHO, A. T. Estudos ecológicos da vegetação como subsídios para programa de revegetação com espécies nativas: uma proposta metodológica. Cerne, Lavras, v. 1, n. 1, p. 113117, 1994.

OOMEN, R. J. F. J.; DAO-THI, B.; TZITZIKAS, E. N.; BAKN, E. J.; SCHOLS, H. A.; VISSER, R. G. F.; VINCKEN, J. P. Overexpression of two different potato UDP-Glc 4epimerases can increase the galactose content of potato tuber cell walls. Plant Science, Amsterdan, v. 166, n. 4, p. 10971104, 2004.

PIÑA-RODRIGUES, F. C. M.; PIRATELLI, A. J. Aspectos ecológicos da produção de sementes. In: AGUIAR, B. de A.; PINA-RODRIGUES, F.C. M.; FIGLIOLA, M. B. Sementes florestais tropicais. Brasília: Abrates, 1993. p. 47-81.

PINHO, D. S.; BORGES, E. E. L.; CORTE, V. B.; NASSER, L. C. B. Avaliação da qualidade fisiológica de sementes de Anadenanthera peregrina (L.) Speg. durante o armazenamento. Revista Árvore, Viçosa, v. 33, n. 1, p. 27 $33,2009$.

PONTES, A. C.; BORGES, E. E. L.; BORGES, R. C. G.; SOARES, C. P. B. Mobilização de reservas em sementes de Apuleia leiocarpa (Vogel) J.F. Macbr. (garapa) durante a embebição. Revista Árvore, Viçosa, v. 26, n. 5, p. 593-601, 2002. 
RÊGO, M. G.; POSSAMAI, E. Jacarandá-da-Bahia (Dalbergia nigra veloso) Leguminoseae-Papiliodae: produção de mudas. Colombo: Embrapa, 2003. (Comunicado técnico, 106).

RODRIGUES, P. M. S.; SILVA, C. H. P.; BRAGA, L. L.; NUNES, W. R. F.; VELOS, M. D. M.; GANZAGA, A. P. D. Efeito da luz e da procedência na germinação de sementes de Copaifera langsdorffii Desf. (Fabaceae - Caesalpinioideae). Revista Brasileira de Biociência, Porto Alegre, v. 5, n. 2, p. 264-266, 2007. Suplemento.

RÖSTI, J.; BARTON, C. J.; ALBRECHT, S.; DUPREE, P.; PAULY, M.; FINDLAY, K.; ROBERTS, K.; SEIFERT, G. J. UDP-Glucose 4-epimerase isoforms UGE2 and UGE4 cooperate in providing UDP-Galactose for cell wall-biosynthesis and growth of Arabdopsis thaliana. Plant Cell, Waterbury, v. 19, p. 1565-1579, 2007.

SOUSA, M. P.; BRAGA, L. F.; BRAGA, J. F.; SÁ, M.; MORAES, M. L. T. Influência da temperatura na germinação de sementes de sumaúma (Ceiba pentandra (Linn.) Gaertn. Bombacaceae. Revista Brasileira de Sementes, Londrina, v. 22, n. 1, p. 110-119, 2000.

STONE, S. L.; GIFFORD, D. J. Structural and biochemical changes in Loblolly pine (Pinus taeda) seeds during germination and early seedling growth: II., storage triacylglicerols and carbohydrates. International Journal Plant Science, Chicago, v. 160 , n. 4, p. 663-671, 1999.

TINÉ, M. A.; CORTELAZZO, A. L.; BUCKERIDGE, M. S. Xyloglucan mobilization in cotyledons of developing plantlets of Hymenaea courbaril L. (Leguminosae-Caesalpinoideae). Plant Science, Amsterdam, v. 154, n. 2, p. 117-126, 2000.

VIANA, S. F. Caracterização de $\alpha$-Galactosidade de soja para hidrólise de oligossacarídeos de rafinose. 2002. 65 p. Dissertação (Mestrado em Bioquímica Agrícola) - Universidade Federal de Viçosa, Viçosa, 2002. 